\title{
Wax gland size according to worker age in Friesella schrottkyi
}

\author{
Cíntia Eleonora Lopes Justino ${ }^{1}$, Fernando Barbosa Noll ${ }^{1}$, Sidnei Mateus ${ }^{2}$, \\ Johan BILLEN ${ }^{3}$ \\ ${ }^{1}$ Depto. Zoologia e Botânica, Universidade Estadual Paulista, Cristóvão Colombo, 2265, São José do Rio Preto, SP \\ 15054-000, Brazil \\ ${ }^{2}$ Departamento de Biologia, Faculdade de Filosofia Ciências e Letras de Ribeirão Preto, Universidade de São Paulo, Av. \\ Bandeirantes, 3900, Ribeirão Preto, SP, Brazil \\ ${ }^{3}$ Zoological Institute, KU Leuven, Naamsestraat 59, Box 2466, B-3000, Leuven, Belgium
}

Received 28 March 2017 - Revised 11 December 2017 - Accepted 4 January 2018

\begin{abstract}
Wax production is one of the stingless bee activities that is related with nest building. We studied wax gland size in workers of the stingless bee Friesella schrottkyi at nine different ages: $0,4,5,8,10,13,14,15$, and 20 days. In the large majority of workers, we observed a conspicuous epithelium in abdominal tergites III, IV, and V. Our results clearly show a link between worker age and wax production in F. schrottkyi. The epithelial thickness reaches its maximum after 13 days, followed by a drastic decline in workers of 15 days old. We observed an unexpected pattern in a minority of workers, however, which showed a decline in epithelial thickness right after emergence. Even though temporal polyethism is well known in Meliponini, some individuals may not perform all the activities inside the colony; therefore, the workers with the unexpected pattern may correspond to those individuals.
\end{abstract}

stingless bees / wax gland / division of labor / nest building

\section{INTRODUCTION}

In stingless bees (Meliponini), division of labor has been reported to be similar to that in honey bees (Kerr and Santos Neto 1953; Sakagami 1982), although the various activities among workers are not as rigidly defined. The duration of each stage depends on the species and on the condition of the colony (Wille 1983; Giannini 1997). Temporal polyethism, the age-dependent task relation found in highly eusocial bees, is partly

Electronic supplementary material The online version of this article (https://doi.org/10.1007/s13592-018-0561-7) contains supplementary material, which is available to authorized users.

Corresponding author: C. Justino,

cintiaelju@gmail.com

Handling editor: James Nieh based on physiological differences among workers (reviewed in Johnson 2010). In general, a worker changes tasks in the colony according to its age: soon after emergence, it will attend the queen and perform tasks related with brood care. Thereafter, it will become active in nest construction, and finally it will be doing foraging activities outside the nest, as observed in Tetragonisca angustula angustula Latreille, Melipona bicolor Lepeletier, and M. marginata Lepeletier (Wilson 1985; Grosso and Bego 2002; Cepeda 2006; Ferreira-Caliman et al. 2010). In honey bees, wax gland activity follows an age-dependent pattern in which wax building is reported to occur at the age of 5 to 20 days and, when the bees get older, an epithelial atrophy in the wax glands occurs (Mota and CruzLandim 1988; Hepburn et al. 1991, 2014). The amount of wax produced is constant among the age cohorts (Hepburn et al. 2014). 
For Meliponini, there is no precise information so far on whether an equally rigid age polyethism exists nor whether the wax glands show a similar age-dependent development (Sakagami and Michener 1962). However, studies regarding the basic aspects of morphology, such as histological observations, have not been completely explored yet. In fact, the age-dependent appearance of the wax glands could be in agreement with previous behavioral observations of other species in Meliponini. In M. marginata, immediately after emergence, the callow workers are quite motionless, and around the second day of their life, they were observed by Ferreira-Caliman et al. (2010) scraping the wax of the comb surface with their mandibles. In this species, the activities with wax remained until 15 days after emergence and consist of adding wax using the hind legs to remove the wax plates that have been recently produced by the tergal wax glands. The use of the hind legs to remove wax plates starts around the fifth day after emergence and continues until the 24th day. Foraging activities started around 22 days after emergence in $M$. marginata (Ferreira-Caliman et al. 2010).

The wax glands in Apis mellifera are formed by a hypertrophied epidermis of abdominal sternites III-VI, and therefore correspond to class-1 glands (these are formed by columnar epithelial cells with secretory activity) according to the standard classification by Noirot and Quennedey (1974). In A. mellifera, the pathway of wax synthesis starts in the subepidermal fat body and oenocytes, from where precursor molecules are taken up by the wax gland epithelium. These will eventually secrete the wax onto the body surface as solid wax plates (Hepburn et al. 1991), which means that three tissues are involved in the process of wax production (Hepburn et al. 2014). The worker bees will collect the wax from the abdominal wax plates with their legs, bring it to their head, and manipulate it with the mandibles to integrate it into the wax comb. Wax production in honey bees is related to the presence of nectar, with a reduction of nest extension by building new cells when nectar collection decreases (Hepburn et al. 2014).

Here, we studied the size and appearance of the wax gland in the stingless bee Friesella schrottkyi to evaluate whether wax gland size at different ages in this species shows a similar pattern to that observed in honey bees and whether there is a relationship between the stingless bees' age and the wax gland appearance.

\section{MATERIAL AND METHODS}

F. schrottkyi is the only known species of the genus Friesella that occurs in the Brazilian states of Espírito Santo, Minas Gerais, and São Paulo (Silveira et al. 2002). Colonies of this meliponine species typically comprise about 300 workers (body size $<4 \mathrm{~mm}$ ) and nest in pre-existing cavities (Nunes et al. 2010). The bees used in this study were collected from four colonies kept in the department of Biology, Universidade de São Paulo, Faculdade de Filosofia Ciências e Letras de Ribeirão Preto. Three to 10 workers were analyzed for each of the nine different age cohorts studied: 0 (newly emerged adults) and 4, 5, 8, 10, $13,14,15$, and 20 days. In order to mark a sufficient number of callow (newly emerged) workers and recapture them in as natural conditions as possible, initially, two colonies were each divided in two nest boxes: the main box, where the queen laid eggs in the new cells, and an annex box in which we placed old cells with black eye pupae from which young bees emerge. The number of adults inside the extra nest box was estimated around one hundred. Both nest boxes were connected by a plastic tube. This connection allowed older bees from the main nest box to assist the pupae in the annex box during their emergence. In each nest, bees could develop their normal activity according to their age (Figure 1) (Friese).

We collected the bees using a manual entomological aspirator. Callow bees were collected every day in the morning in the nest box, where they could be easily recognized by their pale color and slow walking. Bees were marked with one specific color each day during a period of 3 weeks, which allowed us to recognize their day of emergence at the moment of recapture. Around 20-25 callow workers were thus collected in each colony. Marking was done by applying a dot of the non-toxic paint Acrilex ${ }^{\circledR}$ with a wooden toothpick dorsally on the thorax. The marked bees were then put in a glass tube for $20 \mathrm{~min}$ to let the paint 


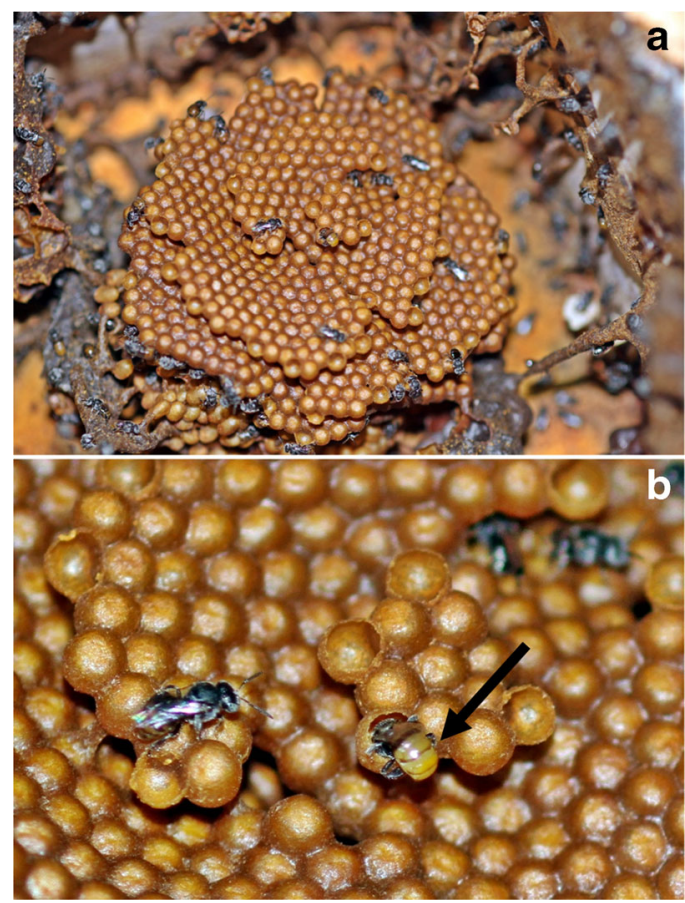

Figure 1. a View of the nest comb of $F$. schrottkyi. b The worker in the center is a wax-building individual as can be recognized by its bright yellow tergites (black arrow). Studied colonies had around 300 workers.

dry and were then introduced again in their colony of origin. We made sure to recapture marked workers until we had reached the minimum of five workers for each age cohort studied. Initially, we performed our study on F. schrottkyi workers of $0,5,10,15$, and 20 days, as these ages are similar to those in the age-dependent wax gland study in A. mellifera Linnaeus by Mota and CruzLandim (1988). However, we found that the crucial period for wax gland development in F. schrottkyi occurs during the first 2 weeks of life. Therefore, we repeated and refined our study with bees from two additional colonies to include also the intermediate ages of $4,8,13$, and 14 days. In this way, workers of $0,5,10,15$, and 20 days of age were taken from two colonies and bees of 4,8 , 13, and 14 days from different colonies. We do not have the detailed data for each individual worker of the various age cohorts from which specific colony it was collected but are confident that this lacking information is not essential for the interpretation of the histological data we obtained.
The posterior part of the abdomen of the bees with the desired age was cut off by making a transverse cut between the second and third abdominal segments with optical surgery microscissors. The abdomen was cut at this site in order to create a sufficiently large opening for the penetration of the various chemicals used during the fixation and dehydration procedure. Preliminary observation confirmed that the second abdominal tergite does not have a wax gland. The abdomen parts were fixed in $2 \%$ glutaraldehyde (buffered at $\mathrm{pH} 7.3$ with $50-\mathrm{mM}$ sodium cacodylate and 150-mM saccharose) and postfixed in $2 \%$ osmium tetroxide in the same buffer. Tissues were dehydrated in a graded acetone series, embedded in Araldite, and sectioned with a Leica EM UC6 ultramicrotome. Serial semithin longitudinal sections with a thickness of $2 \mu \mathrm{m}$ for light microscopy were stained with methylene blue and thionin. Sections were observed in an Olympus BX-51 microscope. The epithelium measurements and images were done using the Olympus DP software. Measurements were made using the software that gives the length of the epithelium by doing a straight line that goes from the top of the wax cell-just under the cuticle to the bottom of the cell (Figure S1-Online resources). We made five measurements in the central portion of the gland epithelium for each tergite of each bee aiming to calculate the average size of the epithelium. As preliminary cross sections had shown that the thickness of the wax gland epithelium is constant within each tergite, thickness measurements were made along the central longitudinal body axis, which could be recognized by the occurrence of the ganglia.

For each individual, we calculated the average epithelium thickness of each tergite from five measurements along the central longitudinal body axis. Mean values for epithelium thickness given in the Supplementary Tables are the arithmetic means of these average values across the investigated bees. After we observed the size pattern of the wax gland in different workers age, we calculated the mean size and standard deviation of the epithelium for three age groups of bees: 0,4 to 14 , and 15 and 20 days, by the sum of the epithelium average size of all individuals of each of the three age groups. 


\section{RESULTS}

Our histological study showed the presence of a conspicuous glandular epithelium with tall cylindrical cells in the abdominal tergites III, IV, and V. The wax glands did not occupy the entire length of the tergite but were mainly localized in the anterior portion of the tergites, whereas the epidermal cells lining the non-glandular parts had a thickness of around $5 \mu \mathrm{m}$, which is much less than the wax gland epithelium in the anterior tergite part (see further). For each worker, the size of the epithelium was similar in the three tergites III, IV, and V (Figures 2 and S2-Online resources).

The epithelial thickness with respect to age for the three tergites is presented in Figure 2, which shows that the epithelium in all callow workers had a thickness around $15 \mu \mathrm{m}$. This thickness increases with increasing worker age, to reach a maximum of 60-70 $\mu \mathrm{m}$ at 13 days (Figure 3e). This was followed by a quick and drastic decline, as the epithelium thickness in workers of 15 days and older hardly measures $5 \mu \mathrm{m}$ (Figure $\mathrm{S} 3 \mathrm{~g}$ - Online resources). This tendency was observed for tergites III, IV, and V (Figure S2-Online resources). In Figure S2 (Online resources), we present the mean size and standard deviation of the gland for the ages of 0,4 to 14 , and 15 and 20 days, to show the size difference when the epithelium is conspicuous and when it is atrophied. The mean values for each age group are presented in the Supplementary Tables (Tables S1 and S2-Online resources). At the age of 0 days $\left(\mathrm{T}_{\mathrm{III}}: 17.96 \mu \mathrm{m} \pm 0.98 ; \mathrm{T}_{\mathrm{IV}}: 16.11 \mu \mathrm{m} \pm 1.19 ; \mathrm{T}_{\mathrm{V}}\right.$ : $13.17 \mu \mathrm{m} \pm 2.20$ ), the epithelium presented an average thickness that was bigger than the thickness at 15 and 20 days $\left(\mathrm{T}_{\mathrm{III}}: 4.00 \mu \mathrm{m} \pm 2.74 ; \mathrm{T}_{\mathrm{IV}}\right.$ : $3.46 \mu \mathrm{m} \pm 1.77$; $\left.\mathrm{T}_{\mathrm{V}}: 2.84 \mu \mathrm{m} \pm 0.76\right)$, but smaller than the secretory epithelium when it presents its maximum thickness (4 to 14 days) ( $\mathrm{T}_{\mathrm{III}}$ : $49.01 \mu \mathrm{m} \pm 12.84 ; \mathrm{T}_{\mathrm{IV}}: 48.04 \mu \mathrm{m} \pm 14.59 ; \mathrm{T}_{\mathrm{V}}$ : $40.24 \mu \mathrm{m} \pm 13.26)$ (Figure S2-Online resource). Regardless of the thickness of the epidermal epithelium, fat cells and oenocytes underneath the epithelium always occurred (Figure S3-Online resource).

At the age of 15 days ( $\mathrm{T}_{\mathrm{III}}: 5.33 \mu \mathrm{m} ; \mathrm{T}_{\mathrm{IV}}$ : $4.18 \mu \mathrm{m}$; $\left.\mathrm{T}_{\mathrm{V}}: 3.12 \mu \mathrm{m}\right)$ the epithelium could not
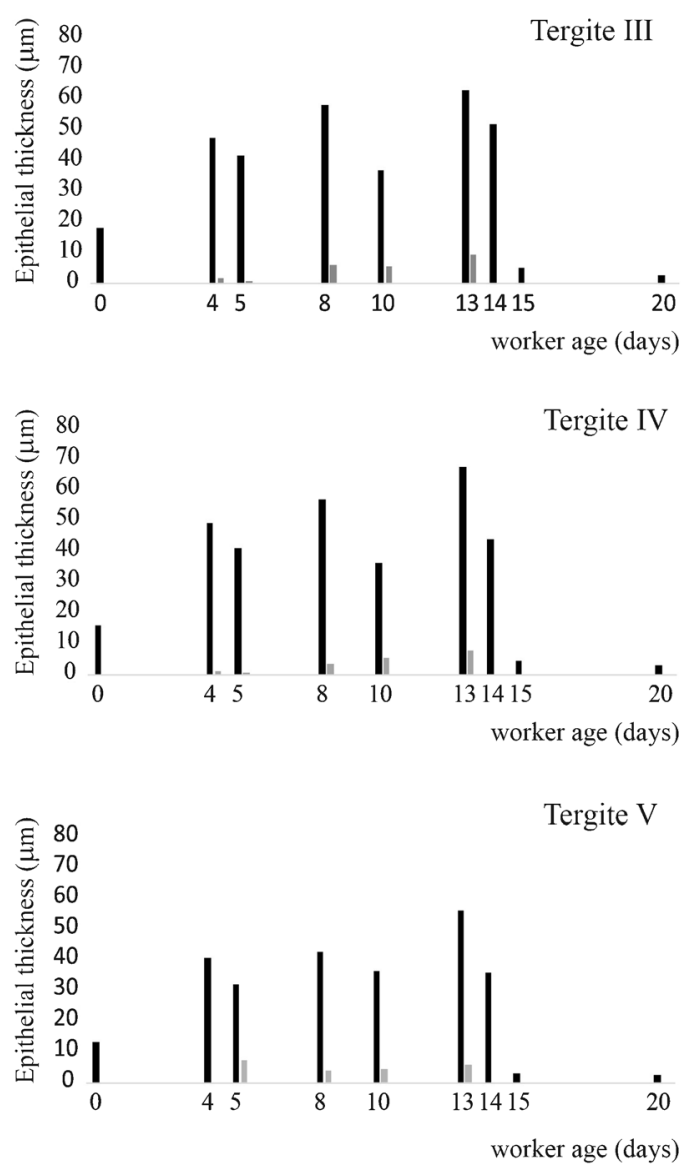

Figure 2. Epithelium thickness for abdominal tergites III, IV, and V. Black bars indicate the mean thickness of the epithelium. Gray bars indicate the mean epithelium thickness for the minority of workers that presented an inconspicuous wax gland epithelium. Three to 10 workers were analyzed for each of the nine different age cohorts.

be recognized as a secretory epithelium since the size of the cell almost reached its minimum height. The minimum height of the epithelium was reached at 20 days $\left(\mathrm{T}_{\mathrm{III}}: 2.69 \mu \mathrm{m} ; \mathrm{T}_{\mathrm{IV}}\right.$ : $3.15 \mu \mathrm{m} ; \mathrm{T}_{\mathrm{V}}: 2.64 \mu \mathrm{m}$ ), which is indicative for a reduced secretory activity after 15 days (Figure 2).

An unexpected observation, however, was that this age-dependent pattern (Figure 2) was valid for the majority of workers studied $(69.23 \%$ of 52 individuals), but not for all of them. The minority of bees (30.77\% of 52 individuals) showed a decline in epithelial thickness in the three tergites 


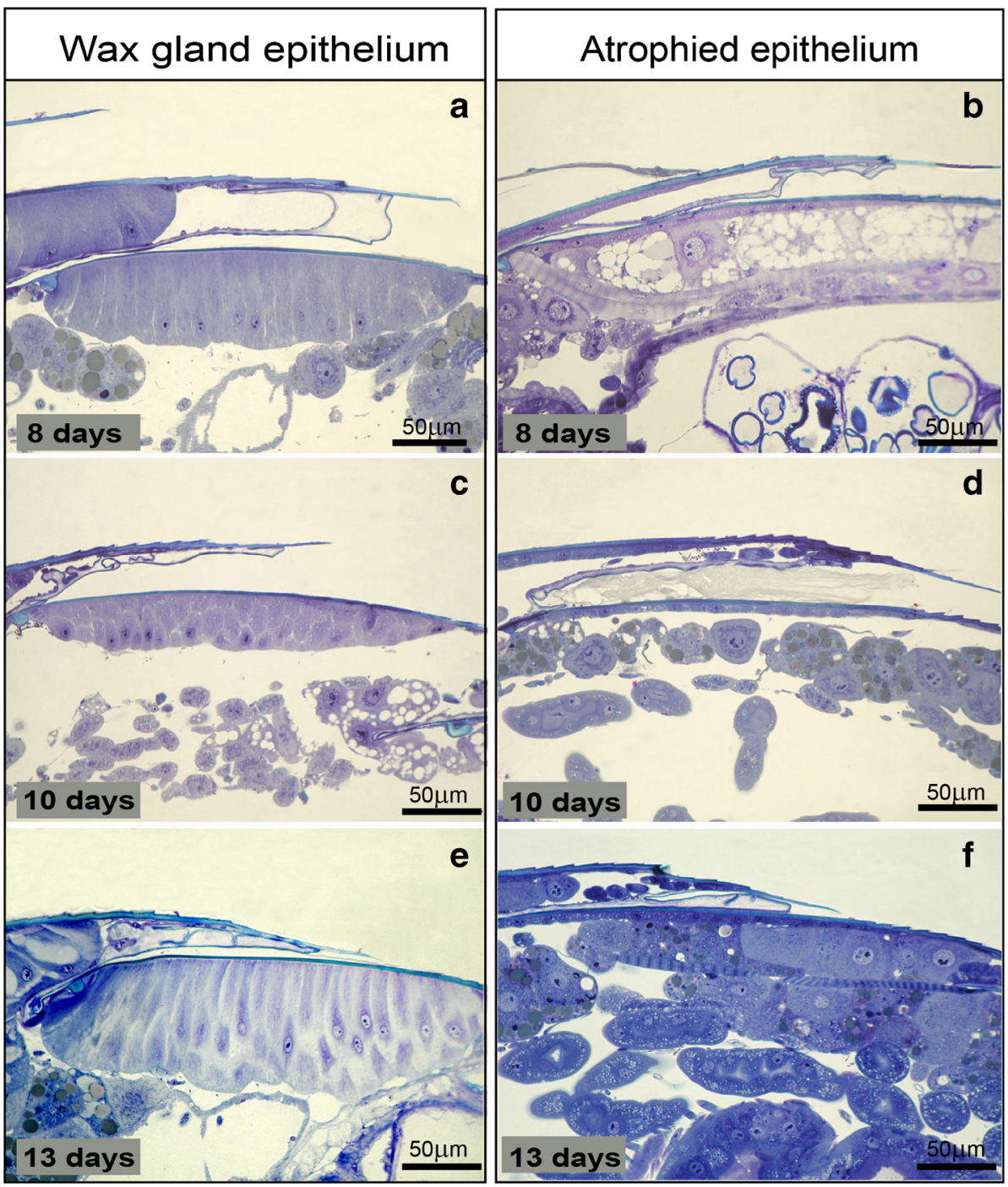

Figure 3. Semithin longitudinal sections of the F. schrottkyi abdomen. Each picture shows the junction between the fourth and fifth abdominal tergites in the majority of workers on the left side and in the minority of workers on right side for different ages. Cuts for histological study were done between second and third abdominal segments.

already 4 days after emergence (Figure 2). They therefore reached the low values of around $5 \mu \mathrm{m}$ of epithelial thickness at least 10 days earlier than the majority of the workers (Figure 2). However, the number of workers that did not follow the pattern of the majority of the workers was different in each age cohort. At 4 days of age, five workers displayed the expected pattern and five did not. At 5 days, five workers showed the expected pattern and two did not. At an age of 8 and
10 days, three workers followed the expected pattern and two did not, and at 13 days, four followed the expected pattern and five did not (Table S2-Online resources).

\section{DISCUSSION AND CONCLUSIONS}

Literature reports dealing with the position of wax glands in stingless bees are rather confusing, as some papers describe them underneath 
abdominal tergites IV to VII (Cruz-Landim 1963), while others mention about abdominal tergites III to VI (Guerino and Paes de Oliveira 2002; CruzLandim 2008). Although these confusing reports all refer to four consecutive tergites, we only found wax glands in the three consecutive abdominal tergites III to V in F. schrottkyi.

Our results confirm a similar pattern of wax gland appearance as found by Mota and CruzLandim (1988) for A. mellifera with a maximum thickness of the wax glands during the second week of adult life (15 days in the honey bee), at least in the majority of workers. After reaching its peak thickness at 13 days, however, the gland degeneration in F. schrottkyi happens faster (at least 5 days) than in A. mellifera. The longevity recorded for $F$. schrottkyi is approximately 30 days (Camillo-Atique unpubl. data), while honey bee longevity is about 35-40 days, rarely exceeding 6 weeks (Sakagami 1982). Regarding these data, the period of wax production in honey bees is at least 5 days longer than that observed in stingless bee species, since they produce wax until the middle of their life, while F. schrottkyi stops its production earlier. Based on behavior, Giannini (1997) observed that in Melipona compressipes fasciculata Smith, the period of working with cerumen took an average of 12 days. This species shows a much longer longevity (around 70 days) than A. mellifera and F. schrottkyi, so production of wax may not be related with longevity.

According to Cruz-Landim (1967), recently emerged honey bees ( 0 days) show an epithelium with flattened cells that cannot be distinguished from the general tegumental epithelium. Our results in F. schrottkyi show that at emergence (0 days), the epithelium in abdominal tergites III, $\mathrm{IV}$, and $\mathrm{V}$ was more pronounced (approximately $10 \mu \mathrm{m}$ ) than at 15 and (approximately $14 \mu \mathrm{m}$ ) at 20 days (Figure $\mathrm{S} 3 \mathrm{a}, \mathrm{g}$ and $\mathrm{h}$-Online resources). This can be understood as the general tegumental epidermis at this stage is still involved in the process of cuticle synthesis, which represents a secretory activity that is different from wax production. As observed in A. mellifera in the period of maximum production of wax, the epithelial cells are columnar (Cruz-Landim 1967) and after 14 days, the epithelium is made up by atrophied cells as described by Snodgrass (1935) and Cruz-Landim
(1967). In Meliponini, bees at the age of 15 days are working with garbage and are involved in construction of nest structures. Therefore, nest building in this period may be more related with handling other materials that meliponine bees use as nest material besides wax. At the age of 20 days, bees are found near the nest entrance, where they receive nectar from the foragers and where they are manipulating resin as observed in M. marginata by Ferreira-Caliman et al. (2010).

Mota and Cruz-Landim (1988) observed that after 10 days, not all honey bee workers presented an actively secreting epithelium, especially in abdominal sternite VI, pointing to the fact that wax secretory activity is not synchronous in this bee species. However, these authors did not further discuss this, neither in terms of behavior nor in terms of numbers of bees that do not present a conspicuous epithelium. In line with these findings in A. mellifera, we could observe the presence of such individuals in which the size pattern of the wax gland was not synchronized with the majority of workers with the same age after 4 days (Figure S3 - Online resource). As our study involved workers from four colonies, each approximately of the same size, the occurrence of a minority of workers with thin wax gland epithelium in all colonies (16 of the total of 52 studied workers, four of 25 in the two first colonies, and 12 of 27 in the two other colonies studied), makes us conclude that our findings are a common characteristic. In the two first colonies, only at 5 and 10 days, we observed individuals with different wax gland appearance from the majority, since at 0,15 , and 20 days the expected pattern does not present secretory activity. In addition, even though size of the four colonies was more or less the same, we do not have data to identify if there were some other conditions, besides the number of workers, which could have an influence on the behavior of the workers that did not follow the expected agedependent pattern of gland appearance.

Behavioral data from $M$. compressipes fasciculata (Giannini 1997) show that around $99.1 \%$ of the workers in a colony were observed working with cerumen and $76.6 \%$ working in cell construction. In addition, Mogho and Wittmann (2013) showed that for Meliponula becarrii (Gribodo), a maximum of $44 \%$ of the total number 
of young workers in the colony was involved in cerumen handling. Some workers, however, never engaged in cell construction (Giannini 1997), which may correspond with the minority group of workers that we observed. Even though honey bees are known for their age-dependent division of labor (Reim and Scheiner 2014), tasks performed by honey bees are not as rigid as generally thought (Sakagami 1982). This flexibility observed in A. mellifera as well as in stingless bees should primarily be an adaptation to the needs of the colony with regard to external and internal conditions (Sakagami 1982; Giannini 1997). In addition, Simões and Bego (1979) verified that if a colony of Scaptotrigona postica (Latreille) is exposed to abnormality (the presence of an attractive virgin queen for example), there is an instability in the tasks performed by the workers that could affect building behavior. A recent study by Grüter et al. (2017) moreover showed that taskrelated worker differentiation in stingless bees evolved repeatedly through history with the eventual development of worker subcastes.

Cruz-Landim (1967) associated the presence of fat cells with wax secretion. These cells are related with the elaboration of wax since they can store lipids (Keeley 1985; Hepburn et al. 1991; Roma et al. 2010). However, fat body cells can perform several other metabolic functions as well and are distributed throughout the body of the insect, especially in the abdomen (Roma et al. 2010). Oenocytes are linked with lipid metabolism and were referred to as wax-producing cells since extractions suggested that they contain particles of waxes (Makki et al. 2014). In F. schrottkyi, we could observe these cells even when the wax glands were not very conspicuous (Figure S3-Online resource), so their function and association with wax production are not entirely clear.

\section{ACKNOWLEDGMENTS}

We are grateful to Alcemir Andrade for permitting us to collect the bee colonies in his property, to An Vandoren for help in section preparation for microscopy, and two anonymous reviewers for their helpful suggestions.

\section{AUTHOR CONTRIBUTIONS}

CELJ, FBN, SM, and JB participated in the design and interpretation of the data. CELJ and JB participated in the data analysis. All the authors participated in the writing. All authors read and approved the final manuscript.

\section{FUNDING INFORMATION}

This research was supported through project 3E150873 from the Explorative Scientific Cooperation Program between UNESP and KU Leuven.

Taille de la glande cirière selon l'âge des ouvrières pour Friesella schrottkyi

abeilles sans aiguillon / glande cirière / division du travail / construction du nid.

Die Grösse der Wachsdrüsen variiert in Abhängigkeit vom Alter der Friesella schrottkyi Arbeiterinnen

Stachellose Biene / Wachsdrüse / Arbeitsteilung / Nestbau

\section{REFERENCES}

Cepeda, O. I. (2006) Division of labor during brood production in stingless bees with special reference to individual participation. Apidologie 37, 175-190

Cruz-Landim, C. (1963) Evaluation of the wax and scent glands in the Apinae (Hymenoptera: Apidae). J. N.Y. Entomol. Soc. 71, 2-13

Cruz-Landim, C. (1967) Estudo comparativo de algumas glândulas das abelhas (Hymenoptera, Apoidea) e respectivas implicações evolutivas. Arq. Zool. 15, $177-290$

Cruz-Landim, C. (2008) Abelhas. Morfologia e função de sistemas. Editora UNESP, São Paulo, SP, 407pp.

Ferreira-Caliman, M. J, Nascimento, F. S., Turatti, I. C., Mateus, S., Lopes, N. P., Zucchi, R. (2010) The cuticular hydrocarbons profiles in the stingless bee Melipona marginata reflect task-related differences. J. Insect Physiol. 56, 800-804

Giannini, K. M. (1997) Labor division in Melipona compressipes fasciculata Smith (Hymenoptera: Apidae: Meliponinae). Ann. Soc. Entomol. Bras. 26, 153-162

Grosso, A. F., Bego, L. R. (2002) Labor division, average life span, survival curve, and nest architecture of 
Tetragonisca angustula angustula (Hymenoptera, Apinae, Meliponini). Sociobiology 40, 615-637

Grüter, C., Segers, F. H. I. D., Menezes, C., Vollet-Neto, A., Falcón, T., von Zuben, L., Bitondi, M. M. G., Nascimento, F. S., Almeida, E. A. B. (2017) Repeated evolution of soldier sub-castes suggests parasitism drives social complexity in stingless bees. Nature Communications $8: 4$. DOI: https://doi.org/10.1038 /s41467-016-0012

Guerino, A. C., Paes de Oliveira, V. T. (2002) Glândulas tegumentares do abdômen, in Cruz-Landim, C., Abdalla, F. C. (Eds) Glândulas exócrinas das abelhas. Editora FUNPEC, Ribeirão Preto, SP. 111-126

Hepburn, H. R., Bernard, R. T. F., Davidson, B. C., Muller, W. J., Lloyd, P., Kurstjens, S. P., Vincent, S. L. (1991) Synthesis and secretion of beeswax in honeybees. Apidologie 22, 21-36

Hepburn, H. R., Pirk C. W. W., Duanghphakdee, O. (2014) Honey bee nests composition, structure, function. Springer Heidelberg New York Dordrecht London. 389pp.

Johnson, B. R. (2010) Division of labor in honeybees: form, function, and proximate mechanisms. Behav. Ecol. Sociobiol. 64, 305-316

Keeley, L. L. (1985) Physiology and biochemistry of the fat body Kerkut, G.A., Gilbert, L.I. (Eds) Comprehensive Insect Physiology, Biochemistry and Pharmacology, vol. 3. Pergamon Press, Oxford, pp 211-248

Kerr, W. E., dos Santos Neto, G. R. (1953) Contribuição para o conhecimento da bionomia dos Meliponini. II. Divisão de trabalho entre as operárias de Melipona quadrifasciata Lep. Cienc. Cult. 5, 224-225

Makki, R., Cinnamon, E., Gould, A. P. (2014). The development and functions of oenocytes. Annu. Rev. Entomol. 59, 405-425

Mogho, N. M. T, Wittmann, D. (2013) Tasks partitioning among workers of Meliponula (Meliplebeia) becarrii (Meliponini) in Cameroon. Int. J. Envir. Sci. 3 , 17961805
Mota, M. H. V. B., Cruz-Landim, C. (1988) Ocorrência e morfometria de glândulas tegumentares abdominais em Apis mellifera L. (Hymenoptera, Apidae). Rev. Bras. Zool. 5 (1), 119-154

Noirot, C., Quennedey, A. (1974) Fine structure of insect epidermal glands. Annu. Rev. Entomol. 19, 61-80

Nunes, T. M., Morgan, E. D., Drijfhout, F. P., Zucchi, R. (2010) Caste-specific cuticular lipids in the stingless bee Friesella schrottkyi. Apidologie 41, 579-588

Reim, T., Scheiner, R. (2014) Division of labour in honey bees: age- and task-related changes in the expression of octopamine receptor genes. Insect Mol. Biol. 23, 833841

Roma, G. C., Bueno, O. C., Camargo-Mathias, M. I. (2010) Morpho-physiological analysis of the insect fat body: a review. Micron 41, 395-401

Sakagami, S. F. (1982) Stingless bees, in Hermann H. R. (Ed.) Social insects. Volume III. Academic Press. New York. pp 362-424

Sakagami, S. F., Michener, C. D. (1962) The nest architecture of sweat bees (Halictinae). University of Kansas Press, Lawrence, p 135

Silveira, F.A., Melo, G.A.R., Almeida, E.A.B. (2002) Abelhas Brasileiras. [online] https://issuu. com/daruich/docs/silveira melo almeida 2002 abelhas_brasileiras (accessed on 1 September 2016 )

Simões, D., Bego, L. R. (1979) Estudos de regulação social em Nannotrigona (Scaptotrigona) postica Latreille, em duas colônias (normal e com rainhas virgens), com especial referência ao polietismo etário (Hym., Apidae, Meliponinae). Bolm. Zool., Univ. S. Paulo, 4, 89-98

Snodgrass, R. E. (1935) Principles of Insect Morphology. McGraw-Hill Book Company. New York and London. $667 \mathrm{p}$.

Wille, A. (1983) Biology of the stingless bees. Annu. Rev. Entomol. 28, 41-64

Wilson, E. O. (1985) The sociogenesis of insect colonies. Science 228, 1489-1495 